Nevada

Environmental

Restoration

Project

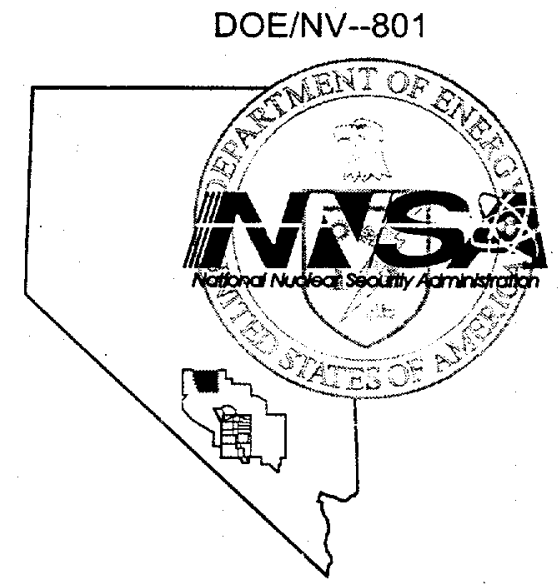

Post-Closure Inspection Report for Corrective Action Unit 426:

Cactus Spring Waste Trenches

Tonopah Test Range, Nevada

Calendar Year 2001

Controlled Copy No.:

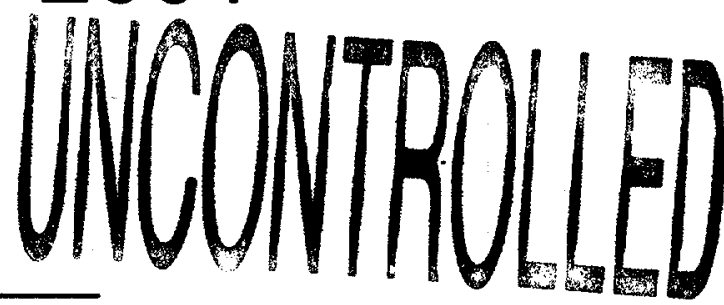

Revision: 0

January 2002

Environmental Restoration

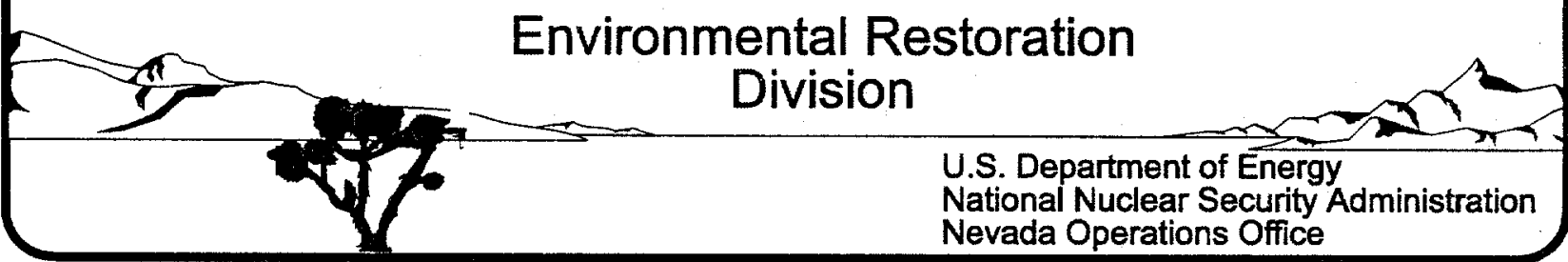




\section{DISCLAIMER STATEMENT}

Reference herein to any specific commercial product, process, or service by trade name, trademark, manufacturer, or otherwise, does not necessarily constitute or imply its endorsement, recommendation, or favoring by the U.S. Government or any agency thereof or its contractors or subcontractors.

\section{AVAILABILITY STATEMENT}

Available for sale to the public from-

U.S. Department of Commerce

National Technical Information Service

5285 Port Royal Road

Springfield, VA 22161-0002

Telephone: 800.553 .6847

Fax: 703.605.6900

E-mail: orders@ntis.fedworld.gov

Online ordering: http://www.ntis.gov/ordering.htm

Available electronically at http://www.doe.gov/bridge

Available for a processing fee to U.S. Department of Energy and its contractors, in paper, from-

U.S. Department of Energy

Office of Scientific and Technical Information

P.O. Box 62

Oak Ridge, TN 37831-0062

Telephone: 865.576 .8401

Fax: 865.576.5728

E-mail: reports@adonis.osti.gov 


\title{
POST-CLOSURE INSPECTION REPORT FOR CORRECTIVE ACTION UNIT 426: CACTUS SPRING WASTE TRENCHES TONOPAH TEST RANGE, NEVADA CALENDAR YEAR 2001
}

\author{
Prepared for \\ U. S. Department of Energy \\ National Nuclear Security Administration \\ Nevada Operations Office \\ Work Performed Under Contract No.
}

DE-AC08-96NV11718

Controlled Copy No.:

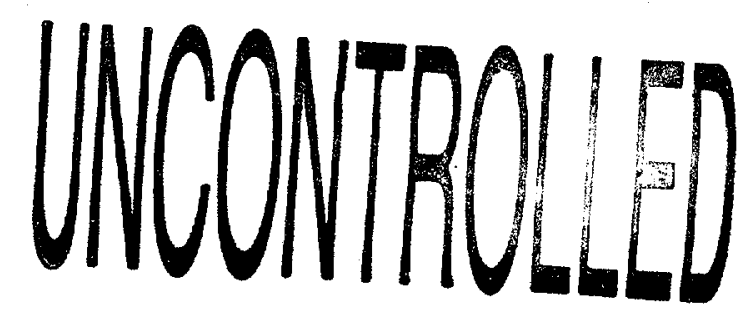

Revision: 0

January 2002 
DOE/NV-801

\section{POST-CLOSURE INSPECTION REPORT FOR CORRECTIVE ACTION UNIT 426: CACTUS SPRING WASTE TRENCHES TONOPAH TEST RANGE, NEVADA CALENDAR YEAR 2001}

Approved by:

Janet L. Appenzeller-Wing, Project Manager Industrial Sites Project

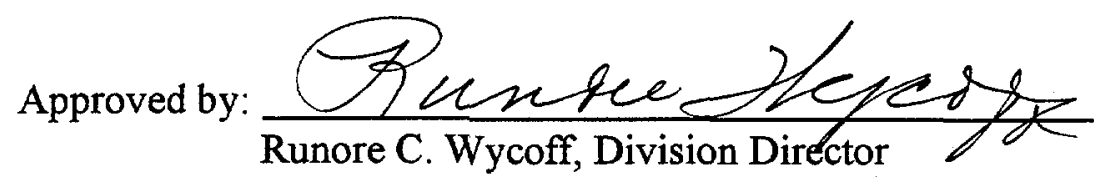

Date: $1 / 28 / 0=$

Date: $1-\partial 8-02$ 


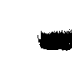




\section{TABLE OF CONTENTS}

1.0 INTRODUCTION $\ldots \ldots \ldots \ldots \ldots \ldots \ldots \ldots \ldots \ldots \ldots \ldots \ldots \ldots \ldots \ldots$

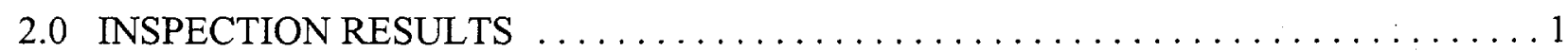

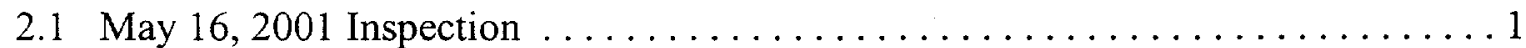

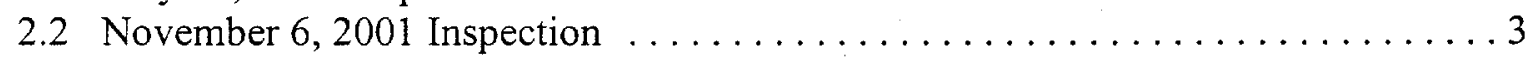

3.0 CONCLUSIONS AND RECOMMENDATIONS $\ldots \ldots \ldots \ldots \ldots \ldots \ldots \ldots \ldots \ldots$

\section{FIGURES}

FIGURE 1 - CACTUS SPRING WASTE TRENCHES CAU 426 LOCATION MAP . . . . . 2

\section{ATTACHMENTS}

ATTACHMENT A - INSPECTION CHECKLISTS

ATTACHMENT B - FIELD NOTES

ATTACHMENT C - PHOTOGRAPH LOG AND PHOTOGRAPHS

DISTRIBUTION LIST 
Post-Closure Inspection Report

Cactus Spring Waste Trenches

Revision: 0

Date: January 24,2002

\section{THIS PAGE INTENTIONALLY LEFT BLANK}




\subsection{INTRODUCTION}

Post-closure monitoring requirements for the Cactus Spring Waste Trenches (Corrective Action Unit [CAU] 426) (Figure 1) are described in Closure Report for Corrective Action Unit 426, Cactus Spring Waste Trenches, Tonopah Test Range, Nevada, report number DOE/NV--226, August 1998. The Closure Report (CR) was submitted to the Nevada Division of Environmental Protection (NDEP) on August 14, 1998. Permeability results of soils adjacent to the engineered cover and a request for closure of CAU 404 were transmitted to the NDEP on April 29, 1999. The CR (containing the Post-Closure Monitoring Plan) was approved by the NDEP on May 13, 1999.

As stated in Section 5.0 of the NDEP-approved CR, Post-Closure Monitoring Plan, site monitoring at CAU 426 consists of the following:

- Visual site inspections done twice a year to evaluate the condition of the cover and plant development.

- Verification that the site is secure and condition of the fence and posted warning signs.

- Notice of any subsidence, erosion, unauthorized excavation, etc., deficiencies that may compromise the integrity of the unit.

- $\quad$ Remedy of any deficiencies within 90 days of discovery.

- $\quad$ Preparation and submittal of an annual report.

Site inspections were conducted on May 16, 2001, and November 6, 2001. All inspections were made after NDEP approval of the CR, and were conducted in accordance with the Post-Closure Monitoring Plan in the NDEP-approved CR.

This report includes copies of the inspection checklists, photographs, recommendations, and conclusions. The Post-Closure Inspection Checklists are found in Attachment A, a copy of the field notes is found in Attachment B, and copies of the inspection photographs are found in Attachment C.

\subsection{INSPECTION RESULTS}

\subsection{May 16, 2001 Inspection}

The first inspection was completed on May 16,2001. The fence, gate, and posted warning signs were all in excellent condition. Numerous small mammal burrows were present along the base of the fence and at the southern and eastern toe of the cover. Burrows along the fence line were filled with soil using a shovel. The burrows have not effected the integrity of the cover. The vegetation present on the cover and in the staging area inside the fence appears very healthy with many native grasses and shrubs present. There is no evidence of erosion of the cover or staging area. The overall condition of the cover and staging area is excellent and no further maintenance or repairs are recommended. 

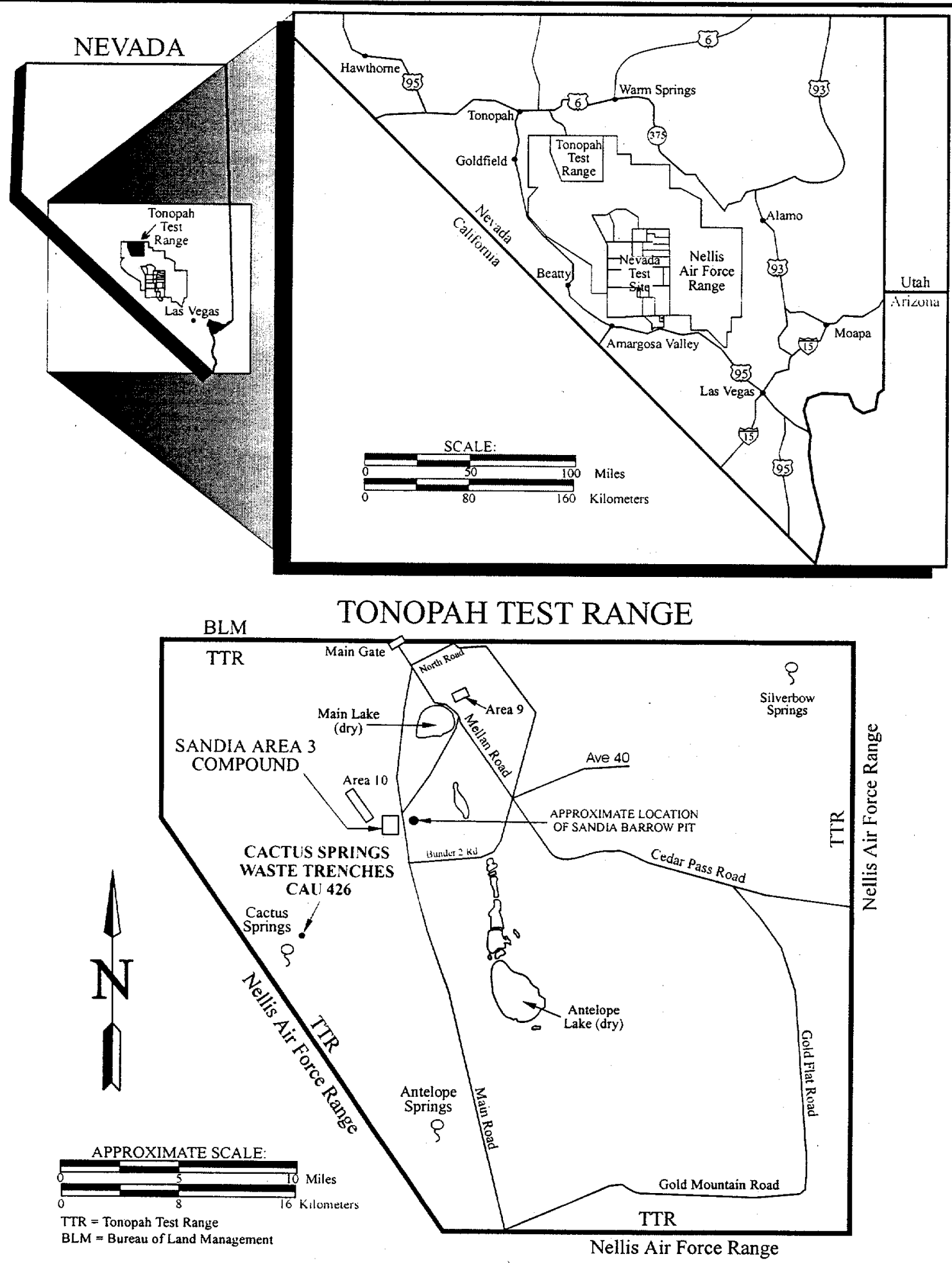

\section{FIGURE 1}

CACTUS SPRING WASTE TRENCHES

CAU 426 LOCATION MAP 


\subsection{November 6, 2001 Inspection}

The second inspection was completed on November 6, 2001. The fence, gate, and posted warning signs were in excellent condition. No breaches through or under the bunny fencing were present. Small and shallow burrowing/scratchings (approximately 5 centimeters [ 2 inches]) to 16 centimeters [ 6 inches] in diameter and depth) were observed along the fence line but not on the cover. Burrows along the fence line were filled with soil. The vegetation on the cover and staging area was healthy with a good variety of native shrubs and grasses present. No noticeable erosion, settling, or cracking of the cover was observed. No further maintenance or repairs are recommended at this time.

\subsection{CONCLUSIONS AND RECOMMENDATIONS}

No evidence of erosion of the cover or staging area was observed in any of the inspections, indicating that the overland run-off is being properly diverted around the cover. Small mammals have burrowed under the fence in several areas but the presence of burrows in the area does not appear to have effected the integrity of the cover. The vegetation on the cover and staging area appears healthy and well established with a good diversity of native plant species. The overall condition of the vegetative cover is excellent.

Monitoring of the vegetation is recommended following the growing season (May/June) in the fifth year after revegetation (2002) as proposed in the $\mathrm{CR}$. No modifications or repairs to the cover or a change in the inspection frequency, are recommended at this time. 
Post-Closure Inspection Report

CAU No. 426

Cactus Spring Waste Trenches

Revision: 0

Date: January 24, 2002

THIS PAGE INTENTIONALLY LEFT BLANK 
Post-Closure Inspection Report CAU No. 426

Cactus Spring Waste Trenches

Revision: 0

Date: January 24, 2002

\section{ATTACHMENT A}

\section{INSPECTION CHECKLISTS}


Post-Closure Inspection Report CAU No. 426

Cactus Spring Waste Trenches

Revision: 0

Date: January 24, 2002

THIS PAGE INTENTIONALLY LEFT BLANK 
CAU 426: CACTUS SPRING WASTE TRENCHES, POST-CLOSURE MONITORING CHECKLIST

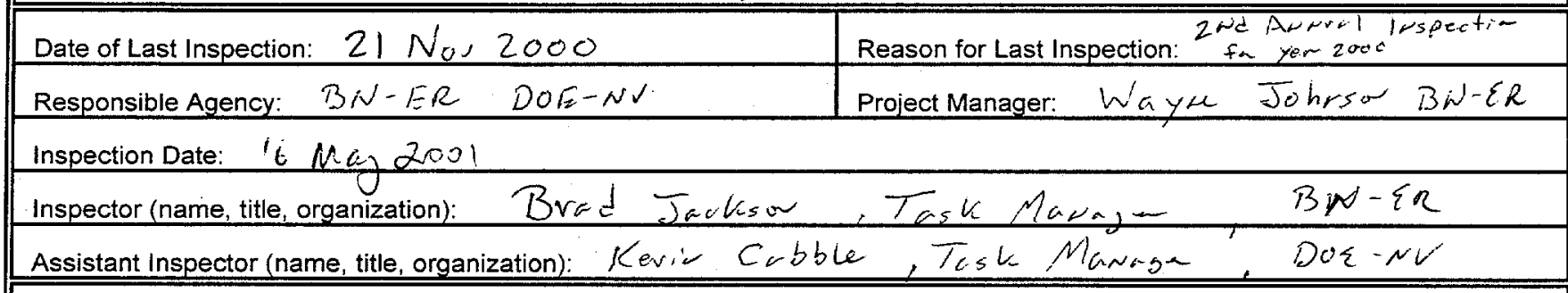

A. GENERAL INSTRUCTIONS

1. All checklist items must be completed and detailed comments made to document the results of the site inspection. The completed checklist is part of the field record of the inspection. Additional pages should be used as necessary to ensure that a complete record is made. Attach the additional pages and number all pages upon completion of the inspection.

3. Any checklist line item marked by an inspector in a SHADED BOX, must be fully explained or an appropriate reference to previous reports provided. The purpose of this requirement is to provide a written explanation of inspector observations and the inspector's rationale for conclusions and recommendations. Explanations are to be placed on additional attachments and cross-referenced appropriately. Explanations, in addition to narrative, will take the form of sketches, measurements, annotated site maps.

4. The site inspection is a walking inspection of the entire site including the perimeter and sufficient transects to be able to inspect the entire surface and all features specifically described in this checklist.

5. A standard set of color $35 \mathrm{~mm}$ photographs (or equivalent) is required. In addition, all anomalous features or new features (such as changes in adjacent area land use) are to be photographed. A photo log entry will be made for each photograph taken.

6. This unit will be inspected biannually with formal reporting to the Nevada Division of Environmental Protection to be done annually. The annual report will include an executive summary, this inspection checklist with field notes and photo log attached, and recommendations and conclusions.

\begin{tabular}{|c|c|c|c|}
\hline B. PREPARATION (To be completed prior to site visit) & YES & No & EXPLANATION \\
\hline 1. Site as-built plans and site base map reviewed. & 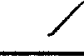 & & \\
\hline \multirow{2}{*}{$\begin{array}{l}\text { 2. Previous inspection reports reviewed. } \\
\text { a. Were anomalies or trends detected on previous } \\
\text { inspections? }\end{array}$} & 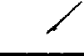 & & \\
\hline & & & \\
\hline b. Was maintenance performed? & & & \\
\hline \multirow{3}{*}{$\begin{array}{l}\text { 3. Site maintenance and repair records reviewed. } \\
\text { a. Has site repair resulted in a change from as-built } \\
\text { conditions? } \\
\text { b. Are revised as-builts available that reflect repair changes? }\end{array}$} & & V & $\sim A$ \\
\hline & & & $N A$ \\
\hline & & & $N A$ \\
\hline C. SITE INSPECTION (To be completed during inspection) & YES & NO & EXPLANATION \\
\hline
\end{tabular}

1. Adjacent off-site features within watershed areas.

a. Have there been any changes in use of adjacent area?

b. Are there any new roads or trails?

c. Has there been a change in the position of nearby washes?

d. Has there been lateral excursion or erosion/deposition of nearby washes?

e. Are there new drainage channels?

f. Change in surrounding vegetation?

\begin{tabular}{|c|c|l|}
\hline & $\nearrow$ & \\
\hline & $\nearrow$ & \\
\hline & $\nearrow$ & \\
\hline & $/$ & \\
\hline & $\nearrow$ & \\
\hline & $\nearrow$ & \\
\hline
\end{tabular}

2. Security fence, signs.

a. Displacement of fences, site markers, boundary markers, or monuments?

b. Have any signs been damaged gr removed? (Number of signs replaced: (1) )

c. Were gates locked?

\begin{tabular}{|c|c|l|}
\hline & $\sqrt{ }$ & \\
\hline & $\mathcal{1}$ & \\
\hline & $\mathcal{N}$ & Ni looks $\rho^{\text {rece-1. }}$ \\
\hline
\end{tabular}


CUA 426: CACTUS SPRING WASTE TRENCHES, POST-CLOSURE MONITORING CHECKLIST

3. Waste Unit cover.

a. Is there evidence of settling?

b. Is there cracking?

c. Is there evidence of erosion around the cap (wind or water)?

d. Is there evidence of animal burrowing?

e. Have the site markers been disturbed by man or natural processes?

f. Do natural processes threaten to integrity of any cover or site marker?

g. Other?

\begin{tabular}{|l|r|l|}
\hline YES & NO & EXPLANATION \\
\hline & $/$ & \\
\hline & $/$ & \\
\hline$/$ & & miron alom marzor ot cop \\
\hline & $/$ & \\
\hline & $/$ & \\
\hline & & NA \\
\hline
\end{tabular}

4. Vegetative cover.

a. Is perimeter fence or mesh fencing damaged?

b. Is there evidence of horses or rabbits on site?

c. Is organic mulch and/or plants adequate to prevent erosion?

d. Are weedy annual plants present? If yes, are they a problem?

e. Are seeded plant species found on site?

f. Is there evidence of plant mortality?

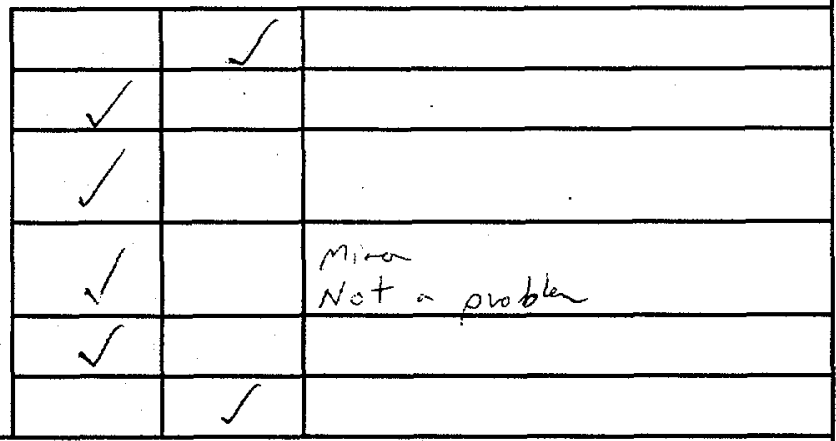

5. Photo Documentation

a. Has a photo log been prepared?

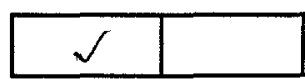

c. Number of photos exposed ( ) ,

\section{FIELD CONCLUSIONS}

1 . Is there an imminent hazard to the integrity of the unit? (Immediate report required)

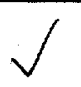

Person/Agency to whom report made:

2. Are more frequent inspections required?

3. Are existing maintenance/repair actions satisfactory?

4. Is other maintenance/repair necessary?

5. Is current status/condition of vegetative cover satisfactory?

6. Rationale for field conclusions: Ne charye sire previons inspection

\section{E. CERTIFICATION}

I have conducted an inspection of the Cactus Spring Waste Trenches, CAU 426, at the TTR in accordance with the Post-Closure Monitoring Plan (see Closure Report) as recorded on this checklist, attached sheets, field notes, photo logs, and photographs.

Chief Inspector's Signature: $2 \mathrm{~h}$ Printed Name: Burd Javicsa

Title: ToskMnNorgon

Date: it may 2001 
CAU 426: CACTUS SPRING WASTE TRENCHES, POST-CLOSURE MONITORING CHECKLIST

\begin{tabular}{|c|c|}
\hline Date of Last Inspection: 16 May $20002001 \mathrm{KBC}$ & Reason for Last Inspection: Semi thinuil Injpetion \\
\hline Responsible Agency: $B N-E R$ DOE-NL & Project Manager: \\
\hline Inspection Date: 8 alorember 2001 & \\
\hline Inspector (name, title, organization): Keven $(\lim <411$ & Chmanl Lad $B N-E=R$ \\
\hline
\end{tabular}

\section{A. GENERAL INSTRUCTIONS}

1. All checklist items must be completed and detailed comments made to document the results of the site inspection. The completed checklist is part of the field record of the inspection. Additional pages should be used as necessary to ensure that a complete record is made. Attach the additional pages and number all pages upon completion of the inspection.

3. Any checklist line item marked by an inspector in a SHADED BOX, must be fully explained or an appropriate reference to previous reports provided. The purpose of this requirement is to provide a written explanation of inspector observations and the inspector's rationale for conclusions and recommendations. Explanations are to be placed on additional attachments and cross-referenced appropriately. Explanations, in addition to narrative, will take the form of sketches, measurements, annotated site maps.

4. The site inspection is a walking inspection of the entire site including the perimeter and sufficient transects to be able to inspect the entire surface and all features specifically described in this checklist.

5. A standard set of color $35 \mathrm{~mm}$ photographs (or equivalent) is required. In addition, all anomalous features or new features (such as changes in adjacent area land use) are to be photographed. A photo log entry will be made for each photograph taken.

6. This unit will be inspected biannually with formal reporting to the Nevada Division of Environmental Protection to be done annually. The annual report will include an executive summary, this inspection checklist with field notes and photo log attached, and recommendations and conclusions.

\section{B. PREPARATION (To be completed prior to site visit)}

1. Site as-built plans and site base map reviewed.

2. Previous inspection reports reviewed.

a. Were anomalies or trends detected on previous inspections?

b. Was maintenance performed?

3. Site maintenance and repair records reviewed.

a. Has site repair resulted in a change from as-built conditions?

b. Are revised as-builts available that reflect repair changes?

C. SITE INSPECTION (To be completed during inspection)

\begin{tabular}{|c|c|l|}
\hline YES & NO & EXPLANATION \\
\hline$\nu$ & & \\
\hline & & \\
\hline & $\checkmark$ & \\
\hline & $\checkmark$ & $N / A$ \\
\hline & $\checkmark$ & $N A$ \\
\hline & $\sim$ & $N A$ \\
\hline YES & NO & EXPLANATION \\
\hline
\end{tabular}

1. Adjacent off-site features within watershed areas.

a. Have there been any changes in use of adjacent area?

b. Are there any new roads or trails?

c. Has there been a change in the position of nearby washes?

d. Has there been lateral excursion or erosion/deposition of nearby washes?

e. Are there new drainage channels?

f. Change in surrounding vegetation?

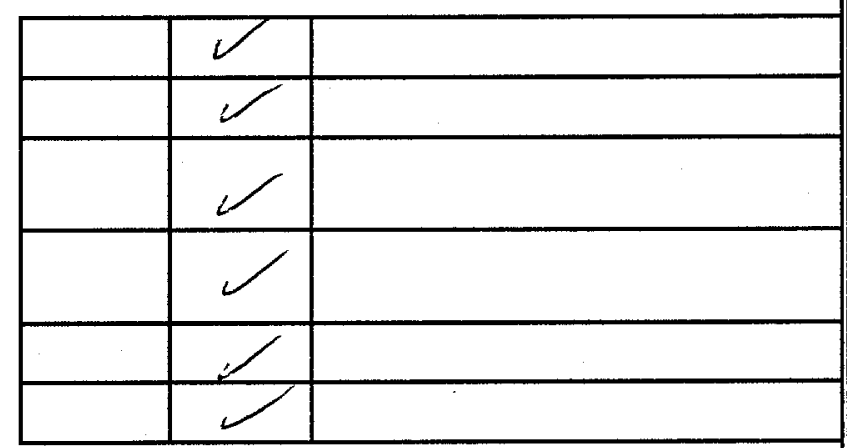

2. Security fence, signs.

a. Displacement of fences, site markers, boundary markers, or monuments?

b. Have any signs been damaged or removed? (Number of signs replaced: $\phi$

c. Were gates locked?

\begin{tabular}{|l|l|l|}
\hline & \multicolumn{1}{|c|}{} \\
\hline & $/$ & \\
\hline & $/$ & no lock present \\
\hline
\end{tabular}




\section{CUA 426: CACTUS SPRING WASTE TRENCHES, POST-CLOSURE MONITORING CHECKLIST}

3. Waste Unit cover.

a. Is there evidence of settling?

b. Is there cracking?

c. Is there evidence of erosion around the cap (wind or water)?

d. Is there evidence of animal burrowing?

e. Have the site markers been disturbed by man or natural processes?

f. Do natural processes threaten to integrity of any cover or site marker?

g. Other?

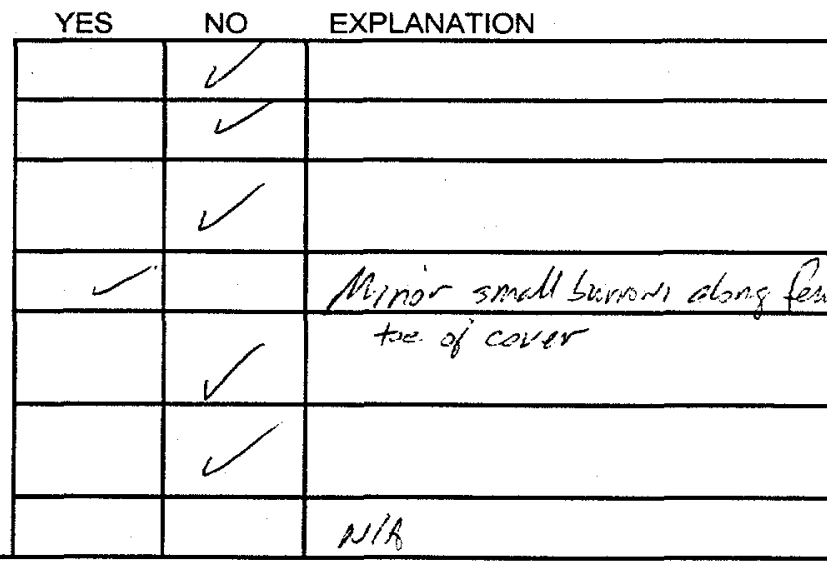

4. Vegetative cover.

a. Is perimeter fence or mesh fencing damaged?

b. Is there evidence of horses or rabbits on site?

c. Is organic mulch and/or plants adequate to prevent erosion?

d. Are weedy annual plants present? If yes, are they a problem?

e. Are seeded plant species found on site?

f. Is there evidence of plant mortality?

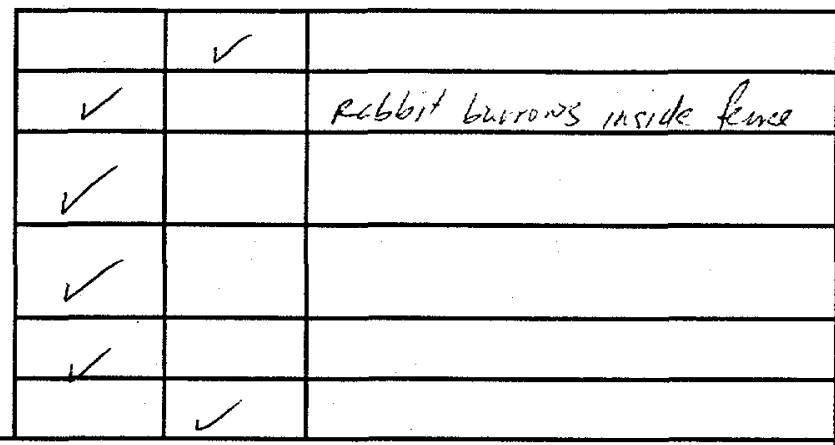

5. Photo Documentation

a. Has a photo log been prepared?

c. Number of photos exposed (5)

\section{FIELD CONCLUSIONS}

1. Is there an imminent hazard to the integrity of the unit? (Immediate report required)

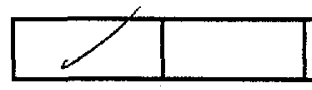

Person/Agency to whorn report made:

2. Are more frequent inspections required?

3. Are existing maintenance/repair actions satisfactory?

4. Is other maintenance/repair necessary?

5. Is current status/condition of vegetative cover satisfactory?

6. Rationale for field conclusions:

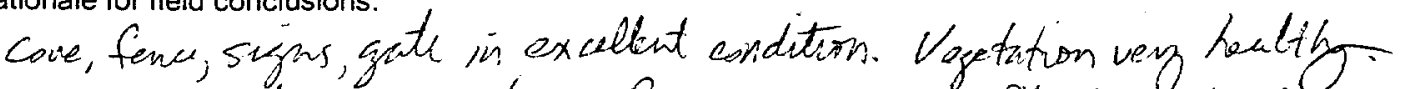

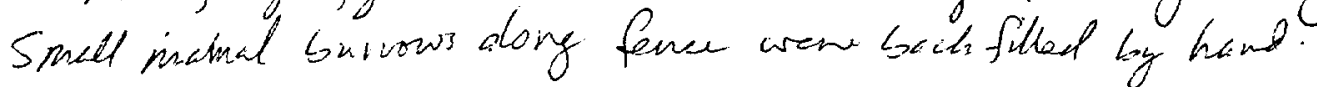

\section{E. CERTIFICATION}

I have conducted an inspection of the Cactus Spring Waste Trenches, CAU 426, at the TTR in accordance with the Post-Closure Monitoring Plan (see Closure Report) as recorded on this checklist, attached sheets, field notes, photo logs, and photographs.

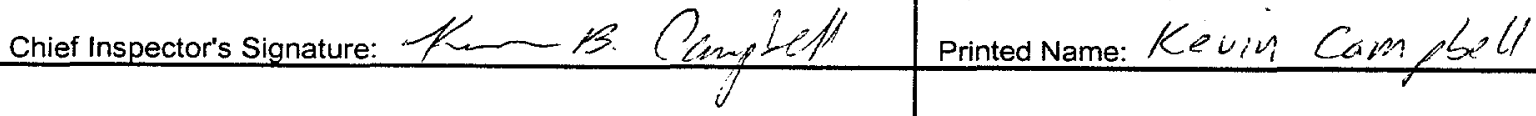

Titie: Technel teal BN-ER

Date: houember Zol 
Post-Closure Inspection Report CAU No. 426

Cactus Spring Waste Trenches

Revision: 0

Date: January 24, 2002

\section{ATTACHMENT B}

\section{FIELD NOTES}


Post-Closure Inspection Report CAU No. 426

Cactus Spring Waste Trenches

Revision: 0

Date: January 24,2002

THIS PAGE INTENTIONALLY LEFT BLANK 
16

TITLE
PROJECT NO.

BOOK NO.

16 May of

$\sim 1430-$ Doublet pit

- Walk the fife line to visually inspect th site.

The fenced ac h was well covered with vegetation

5 ard was in shod condition, Numerous extant \& half bumbles were desert adjacent to the fere or the exterior of the site. Severe bamblets were also present within the ferne area.

$10 \sim 1500$ - Roller Coaster Sewage Lafoows

- walled the exterior fence line of site. The site was in good condition ard well covers with vesetrtior. Two posted fere sises were dow r. A large burrow was present or the east side of .5 the cap margin and a lares ariel appeared to be present is the burrow at the tire of inspection. Two pieces of ved-clay pipe we te present or th south east mario of the fenced ave wen the base of the cap slope. The pipe appeared to extend.

0 undergrad. No notable signs of erosion of ac observed.

$\sim 1545$ - Cactus Springs Waste Trenches.

- walked the exterior farce lime to vievillo inspect the site.

The site and ferries wee ir good condition ard cell covert with vesetrtior. No signs of evasion were observed. The eviterion of the east margin. file site constringe a large quality of tumble needs.

SCIENTIFIC BINDERY PRODUCTIONS CHICAGO 60605 Made in USA

SIGNATURE
Work continued to Page

DATE

WITNESS

DATE 
PROJECT NO.

25

Work continued from Page 24

BOOK NO.

1410 start Area 3 septic harte systems (CAn 427) inspection

Using metal detain to locke basel conner markers

All signs ( 4 total) in excellent condition.

No vegetation as area is heavily treffried.

No symifient erosion features.

Site si good conditur.

Were minable to locate markers for Pe 1965 -less hied

1455 Completed An 3 Septic Waste Systems (e AU 427) inspection.

101500 loading to Castes (C AU426)

1513 Arrive at cactus

Fence sign gate in excellent condition

small manual burnous at base of fencer

vegetitum very heathy, no significant enonon features

15 Cover Corks in excellent competition

Depart Cactus for Area 3 .

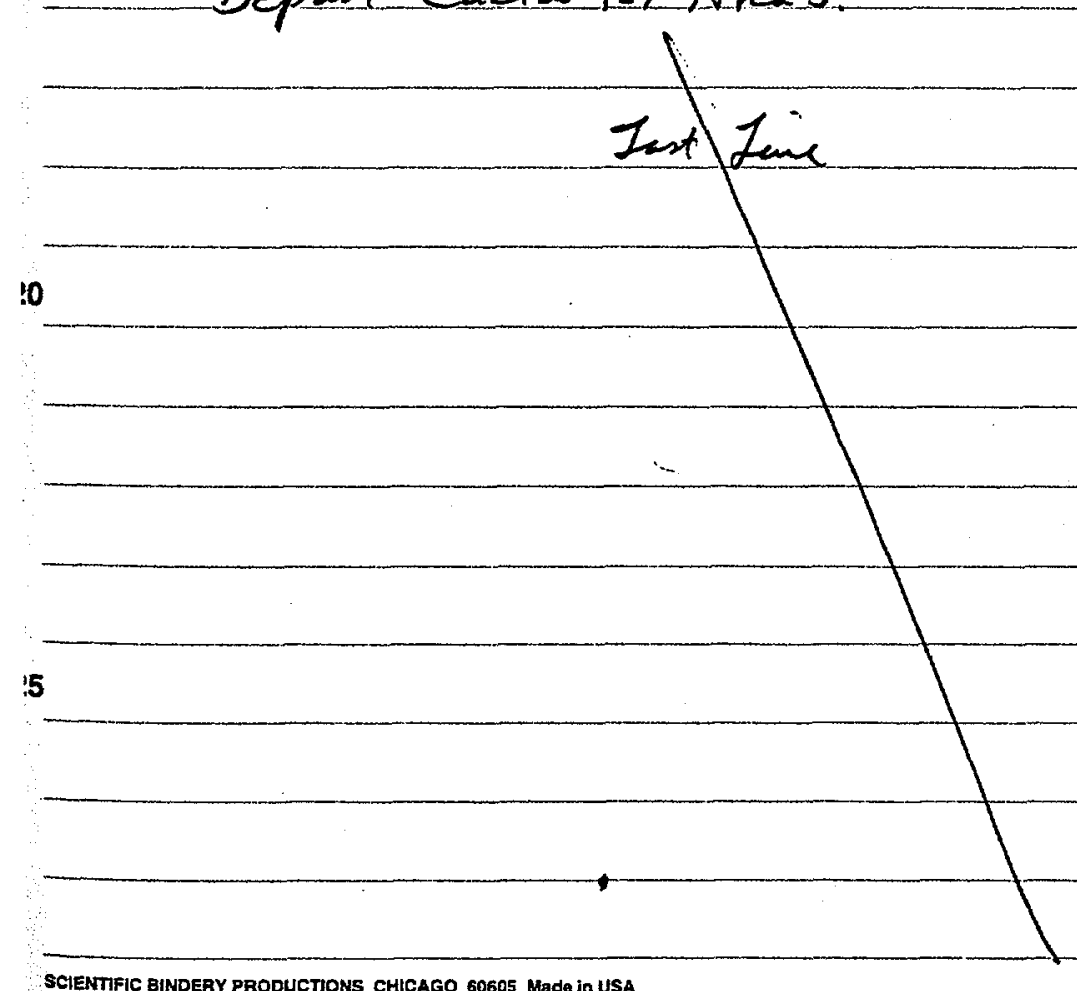

SCIENTIFIC BINDERY PRODUCTIONS CHICAGO 60605 Made in USA

Work continued to Page NLA SIGNATURE

DISCLOSED TO AND UNDERSTOOD BY

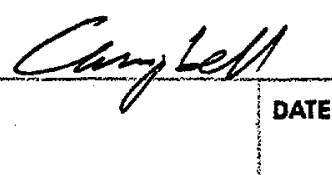

DATE WITNESS $\frac{\text { DATE }}{1 / 1 / 6 / \% 1}$ 
Post-Closure inspection Report

C.AU No. 426

Cactus Spring Waste Trenches

Revision: 0

Date: January $24.20(02$

\section{ATTACHMENT C}

\section{PHOTOGRAPH LOG AND PHOTOGRAPHS}


Post-Closure Inspection Report CAU No. 426

Cactus Spring Waste Trenches

Revision: 0

Date: January 24, 2002

$-$

-

THIS PAGE INTENTIONALLY LEFT BLANK

- 


\section{PHOTOGRAPH LOG}

\begin{tabular}{|c|c|c|}
\hline $\begin{array}{c}\text { PHOTO } \\
\text { NUMBER } \\
\end{array}$ & DATE & DESCRIPTION \\
\hline 1 & $05 / 16 / 2001$ & $\begin{array}{l}\text { View of the cover and staging area looking east. Vegetation is } \\
\text { very healthy inside fenced area. }\end{array}$ \\
\hline 2 & $05 / 16 / 2001$ & $\begin{array}{l}\text { View of the east end of cover looking west. Vegetation is very } \\
\text { healthy at the base of the cover and on the cover. }\end{array}$ \\
\hline 3 & $05 / 16 / 2001$ & View to the north of southern side of cover from inside fence. \\
\hline 4 & $05 / 16 / 2001$ & $\begin{array}{l}\text { View to the northeast of the cover of west and south sides of } \\
\text { cover. }\end{array}$ \\
\hline 5 & $11 / 06 / 2001$ & $\begin{array}{l}\text { View to the east of gate and fenced area. Vegetation inside } \\
\text { fenced area is well established and healthy; it is as dense as } \\
\text { vegetation outside the fence in undisturbed area. }\end{array}$ \\
\hline 6 & $11 / 06 / 2001$ & View to the east of staging area and cover from inside the fence. \\
\hline 7 & $11 / 06 / 2001$ & View to the south of east edge of cover from inside the fence. \\
\hline 8 & $11 / 06 / 2001$ & $\begin{array}{l}\text { View to the west of east edge of cover from inside the fence. } \\
\text { Vegetation is well established, healthy and as dense as } \\
\text { undisturbed areas outside the fence. }\end{array}$ \\
\hline
\end{tabular}


Post-Closure Inspection Report CAU No. 426

Cactus Spring Waste Trenches

Revision: 0

Date: January 24,2002

THIS PAGE INTENTIONALLY LEFT BLANK 


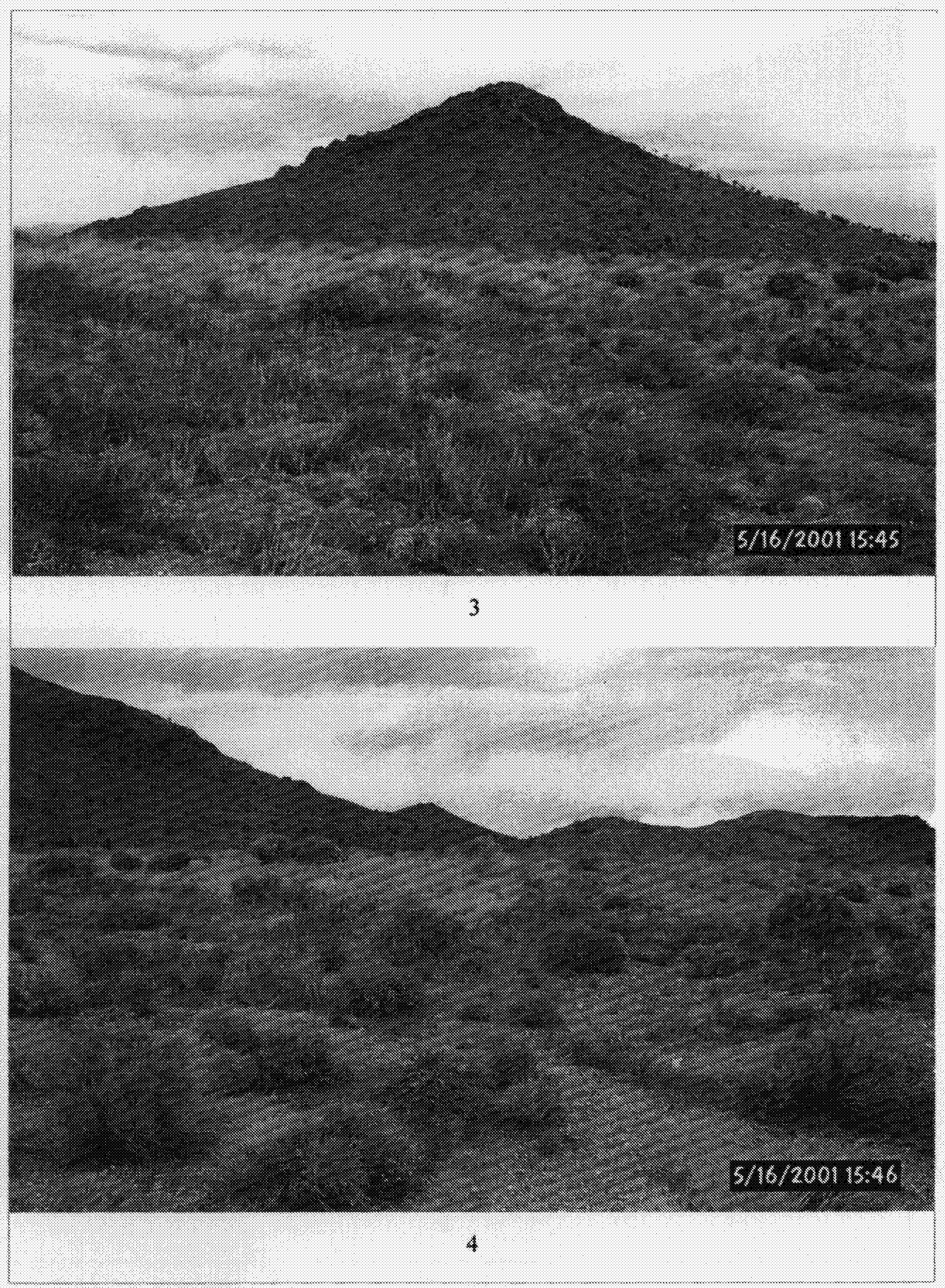



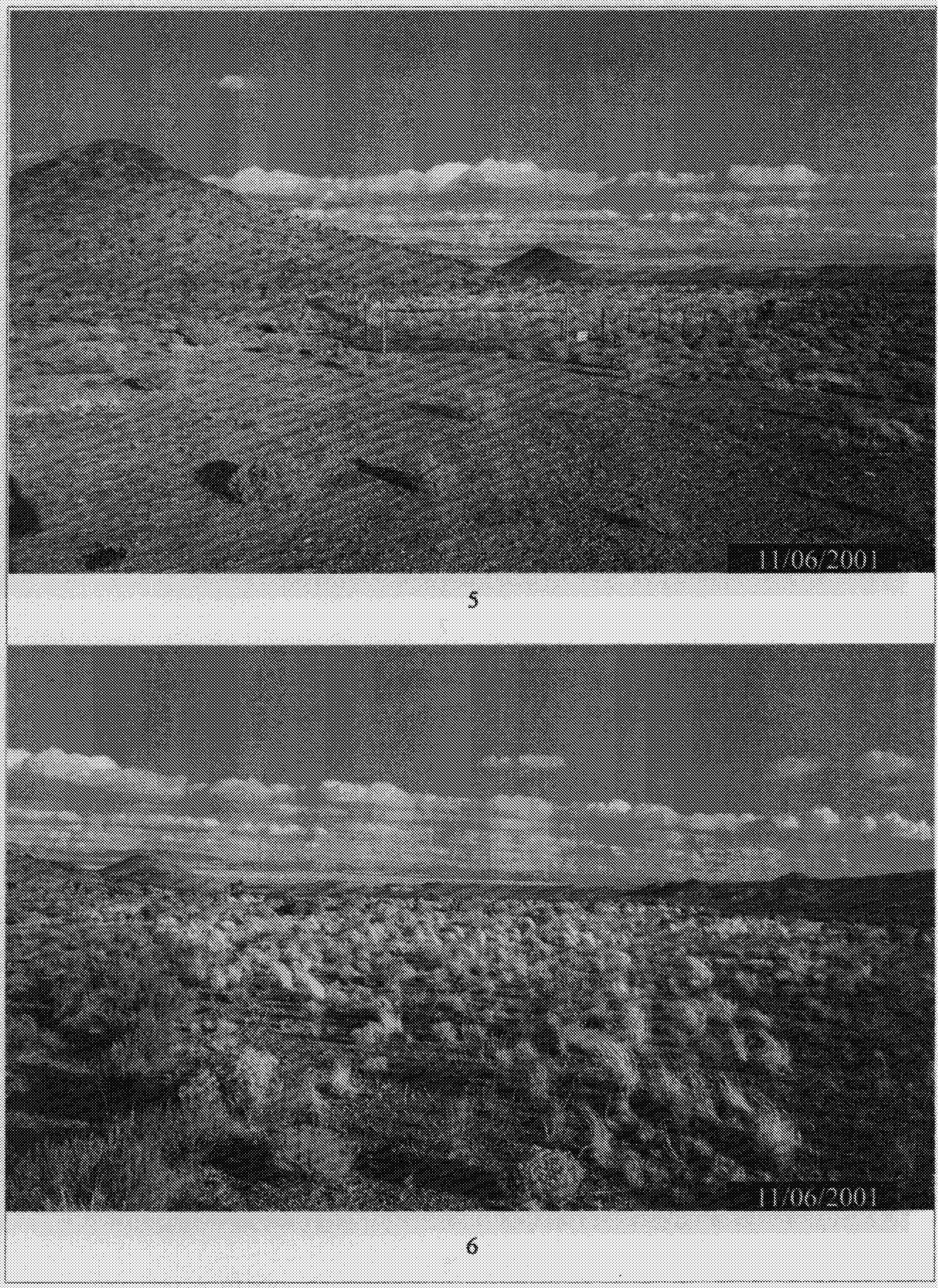


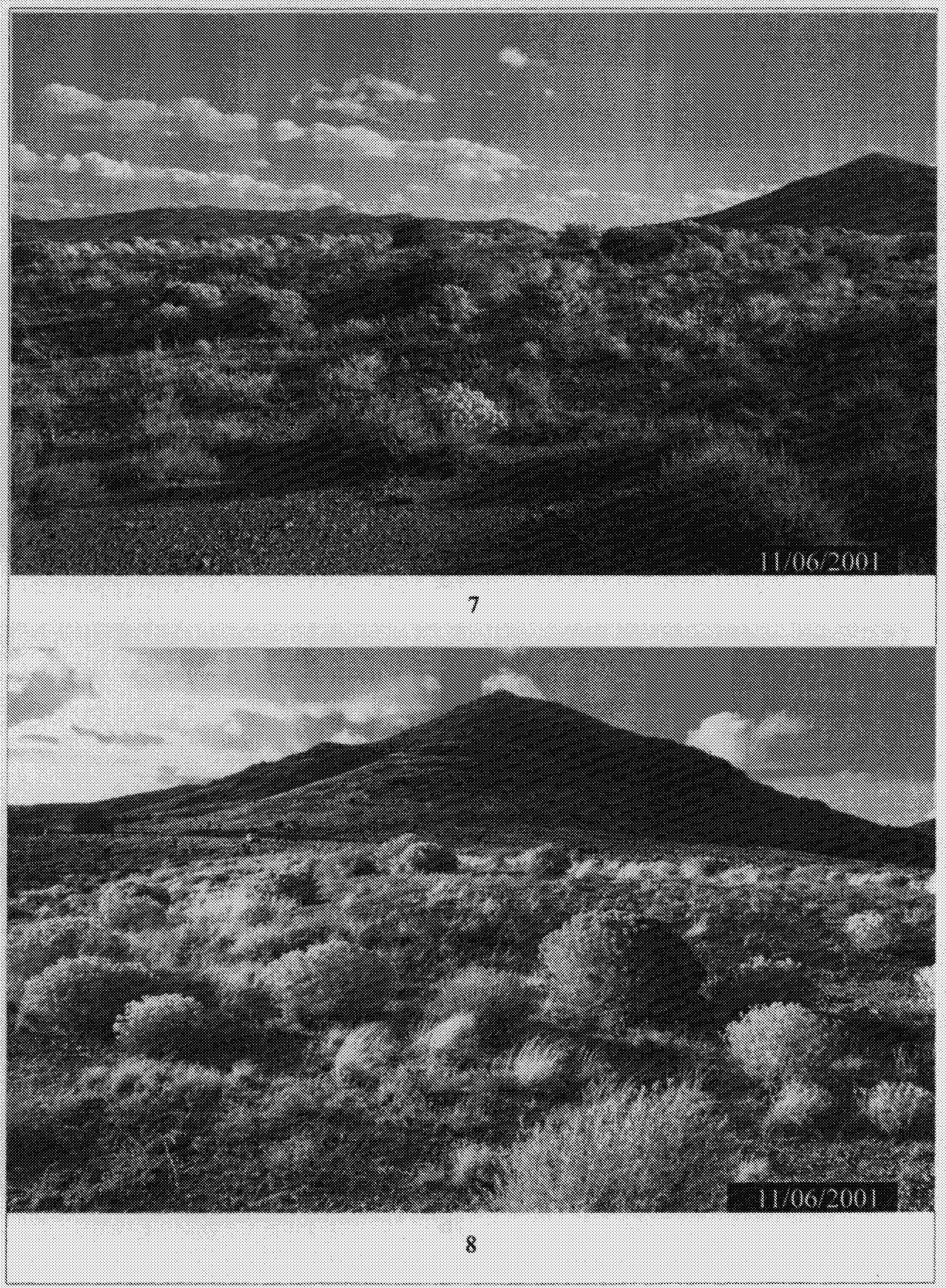


Post-Closure Inspection Report

CAU No. 426

Cactus Spring Waste Trenches

Revision: 0

Date: January 24,2002

DISTRIBUTION LIST 
Post-Closure Inspection Report

CAU No. 426

Cactus Spring Waste Trenches

Revision: 0

Date: January 24, 2002

THIS PAGE INTENTIONALLY LEFT BLANK 


\section{DISTRIBUTION LIST}

*Provide copy of initial distribution of Revision 0; remainder of list gets Revision 0 if approved without changes. The entire list receives Revision 1, if issued.

\section{Nevada Department of Environmental Protection}

Paul Liebendorfer

2 (Controlled)* $^{*}$

Bureau of Federal Facilities

Division of Environmental Protection

333 W. Nye Lane, Room 138

Carson City, NV 89706-0866

Supervisor, Las Vegas Office

1 (Controlled)* $^{*}$

Bureau of Federal Facilities

Division of Environmental Protection

555 E. Washington, Suite 4300

Las Vegas, NV 89010-1043

\section{U.S. Department of Energy}

Janet Appenzeller-Wing

1 (Uncontrolled)*

Project Manager

Environmental Restoration Division

U.S. Department of Energy

National Nuclear Security Administration

Nevada Operations Office

P.O. Box $98518 \mathrm{M} / \mathrm{S} 505$

Las Vegas, NV 89193-8518

Kevin Cabble

1 (Uncontrolled)*

Environmental Restoration Division

U.S. Department of Energy

National Nuclear Security Administration

Nevada Operations Office

P.O. Box $98518 \mathrm{M} / \mathrm{S} 505$

Las Vegas, NV 89193-8518

Sabrina Lawrence

1 (Controlled)*

Environmental Restoration Division

U.S. Department of Energy

National Nuclear Security Administration

Nevada Operations Office

P.O. Box $98518 \mathrm{M} / \mathrm{S} 505$

Las Vegas, NV 89193-8518 


\section{DISTRIBUTION LIST (Continued)}

\section{U.S. Department of Energy (continued)}

U.S. Department of Energy

1 (electronic copy)

Office of Scientific and Technical Information

P.O. Box 62

Oak Ridge, TN 37831-0062

U.S. Department of Energy

National Nuclear Security Administration

1 (Controlled) \&

Nevada Operations Office

1 (Uncontrolled)

Public Reading Facility

P.O. Box $98521 \mathrm{M} / \mathrm{S}$ NLV040

Las Vegas, NV 89193-8521

U.S. Department of Energy

1 (Uncontrolled)

National Nuclear Security Administration

Nevada Operations Office

Technical Information Resource Center

P.O. Box $98521 \mathrm{M} / \mathrm{S} 505$

Las Vegas, NV 89193-8521

\section{Bechtel Nevada}

Correspondence Control

1 (Uncontrolled)*

Bechtel Nevada

P.O. Box $98521 \mathrm{M} / \mathrm{S}$ NLV008

Las Vegas, NV 89193-8521

Environmental Management Library

1 (Uncontrolled)*

Bechtel Nevada

P.O. Box 98521 N/S NLV080

Las Vegas, NV 89193-8521

Kevin Campbell

1 (Uncontrolled)* $^{*}$

Bechtel Nevada

P.O. Box $98521 \mathrm{M} / \mathrm{S}$ NTS306

Las Vegas, NV 89193-8521

Ann Heidema

1 (Uncontrolled)

Bechtel Nevada

P.O. Box $98521 \mathrm{M} / \mathrm{S}$ NLV022

Las Vegas, NV 89193-8521 


\section{DISTRIBUTION LIST (Continued)}

\section{Bechtel Nevada (continued)}

Ronald Jackson

1 (Uncontrolled)*

Bechtel Nevada

P.O. Box $98521 \mathrm{M} / \mathrm{S}$ NTS306

Las Vegas, NV 89193-8521

Wayne Johnson

1 (Uncontrolled)*

Bechtel Nevada

P.O. Box $98521 \mathrm{M} / \mathrm{S}$ NTS306

Las Vegas, NV 89193-8521

Steve Nacht

1 (Uncontrolled)*

Bechtel Nevada

P.O. Box $98521 \mathrm{M} / \mathrm{S}$ NTS306

Las Vegas, NV 89193-8521

\section{IT Corporation}

Lynn Kidman

1 (Uncontrolled)*

IT Corporation

P.O. Box 93838 M/S 439

Las Vegas, NV 89193-8521

Garry Romano

1 (Controlled)

IT FFACO Support Office

IT Corporation

P.O. Box 93838 M/S 439

Las Vegas, NV 89193-8521

\section{State Of Nevada}

Manager, Northern Nevada

FFACO Public Reading Facility

1 (Controlled) \&

Nevada State Library and Archives Federal Publications

1 (Uncontrolled) 100 North Stewart Street

Carson City, NV 89701-4285 